The University of San Francisco

USF Scholarship: a digital repository @ Gleeson Library |

Geschke Center

2009

\title{
Venture Capitalists' Confidence, Capital Commitments, and Capital Investments
}

Mark V. Cannice

University of San Francisco, cannice@usfca.edu

Cathy S. Goldberg

University of San Francisco, goldberg@usfca.edu

Follow this and additional works at: http://repository.usfca.edu/esib

Part of the Finance and Financial Management Commons

\section{Recommended Citation}

Mark V. Cannice, Cathy S. Goldberg. Venture Capitalists Confidence, Capital Commitments, and Capital Investments. Int. J. of Technoentrepreneurship 2009 - Vol. 2, No.1 pp. 79-98.

This Article is brought to you for free and open access by the School of Management at USF Scholarship: a digital repository @ Gleeson Library | Geschke Center. It has been accepted for inclusion in Entrepreneurship, Innovation, and Strategy by an authorized administrator of USF Scholarship: a digital repository@ Gleeson Library | Geschke Center. For more information, please contact repository@usfca.edu. 


\title{
Venture capitalists' confidence, capital commitments, and capital investments
}

\section{Mark V. Cannice* and Cathy S. Goldberg}

University of San Francisco,

School of Business and Management,

2130 Fulton Street, San Francisco, CA 94117

Fax: 415.422.2502

E-mail: Cannice@usfca.edu

E-mail: Goldberg@usfca.edu

${ }^{*}$ Corresponding author

\begin{abstract}
Confidence among consumers and managers continues to be a closely watched economic indicator. Venture capitalists are essential in the development of many high-growth ventures; however, VC sentiment has not before been systematically tracked. We surveyed VC confidence quarterly since Q1 2004 and find that increasing VC confidence is coincident with increasing VC investment; however, VC confidence decreases one quarter after their increased investment activity, possibly due to buyer's remorse. Additionally, VC confidence decreases one quarter after increasing capital commitments to $\mathrm{VC}$ industry funds, possibly due to concern of too much money chasing too few good deals.
\end{abstract}

Keywords: venture capital; VC confidence; capital commitments; capital investments; portfolio firms; Silicon Valley.

Reference to this paper should be made as follows: Cannice, M.V. and Goldberg, C.S. ( $\mathrm{xxxx)}$ 'Venture capitalists' confidence, capital commitments, and capital investments', Int. J. Technoentrepreneurship, Vol. x, No. $\mathrm{x}, \mathrm{pp} \cdot \mathrm{xxx}-\mathrm{xxx}$.

Biographical notes: Mark V. Cannice is an Associate Professor of Entrepreneurship with the University of San Francisco's School of Business, and the Founder/Executive Director of the USF Entrepreneurship Program. He publishes the quarterly Silicon Valley Venture Capitalist Confidence Index Report carried globally by Bloomberg Professional Services and referenced by the Wall Street Journal, NY Times, CNBC, NPR, etc. He has published in leading academic journals and is the co-author of Management: A Global and Entrepreneurial Perspective, 12th edition (McGraw-Hill), He holds a $\mathrm{PhD}$ and MS from Indiana University, an MBA from USF, and BS from the US Naval Academy (Annapolis).

Cathy S. Goldberg is an Associate Professor of Finance at the University of San Francisco's School of Business and Management where she has been recognised as the university's best teacher. She received her $\mathrm{PhD}$ in Finance from the University of Colorado, Boulder, her Master's in Teaching (Mathematics) from Tulane University, New Orleans, and her Bachelor of Commerce in Finance and Management Information Systems from McGill University, Montreal, Quebec, Canada. She also has several years of finance 
industry experience, having worked on Wall Street as an investment banker for Salomon Brothers. Her current research focuses on venture capital industry issues as well as on emerging markets, specifically addressing financial integration, country risk and currency contagion.

\section{Introduction}

Venture capital firms, which are a subset of the private equity industry that focuses on financing private early stage high-growth potential firms (Hand, 2007), operate at the intersection of the private and public capital markets. The VC business model essentially involves raising capital for their portfolio funds from private sources such as pension funds, endowments, etc. (capital commitments), and identifying high potential new ventures and taking an ownership stake in some of these firms in exchange for strategic guidance and financing (capital investments). VCs then eventually sell their ownership stake in their portfolio firms through a liquidity event, normally in the public markets, through an acquisition by a publicly held firm or an initial public offering of their portfolio firm, ideally at a multiple of the value of their initial ownership stake (return of and on their invested capital).

We reasoned that venture capitalists' confidence is related to their expectation of success in completing each aspect of their business model. In other words, we expect that VCs should feel more confident when they are able to raise sufficient capital commitments from their limited partners, identify and invest in high potential new ventures, and take these firms to a successful exit through an M\&A or IPO. We believe that $\mathrm{VC}$ confidence is an important construct to capture and track as their level of confidence may provide an indication of the continuing health of the high-growth entrepreneurial economy. ${ }^{1}$ In essence, if VCs are feeling confident, we expect that this bodes well for their ability and willingness to invest in high potential entrepreneurial ventures. ${ }^{2}$ Therefore, we propose that a better understanding of the relationship between venture capitalists' confidence and venture capital flows may provide additional insights for decisions made by entrepreneurs and public policy makers.

Confidence has been defined as the quality or state of being certain. ${ }^{3}$ This state of certainty is normally linked to the anticipation of a positive outcome. In our research, we sought to study our responding venture capitalists' confidence in the future high-growth venture entrepreneurial environment (next 6-18 months) in the San Francisco Bay Area, and we structured our quarterly survey for that effect. We then examined the relationship between changes in $\mathrm{VC}$ confidence and changes in capital commitments to VC funds and capital investments by VCs in their portfolio companies.

While prior studies have examined the fund raising activities (soliciting capital commitments) of venture firms (Gompers and Lerner, 1998; Jeng and Wells, 2000; Gompers et al., 2005), they have not linked these activities to the confidence held by venture capitalists. We expect that $\mathrm{VC}$ confidence could have a meaningful relationship with the relative success of their fundraising efforts and, therefore, on their ability to finance high potential new ventures. 
Other studies have examined the selection criteria that VCs use in choosing which start-ups companies to invest in MacMillan et al. (1985), Hall and Hofer (1993), Jeng and Wells (2000) and Shepherd and Zacharakis (2002), the optimal portfolio size (in terms of companies funded) held by venture capital firms (Cumming, 2006; Bernile et al., 2007), and the syndication of VC investments (Wilson, 1968; Lerner, 1994a; Lockett and Wright, 2001; Sorenson and Stuart, 2001; Wright and Lockett, 2003; Manigart et al., 2006; Hochberg et al., 2007), among a network of venture capital firms, but these studies have not linked these investment decisions to the underlying confidence that VCs held in the entrepreneurial environment. Again, we reasoned that VC confidence may have an important impact on the total capital investment in their portfolio firms and, thus, the availability of financing for high-growth ventures.

We sought to contribute to the existing literature in this stream of venture capital research by introducing and exploring the phenomenon of venture capitalists' confidence, and by tracking VCs' confidence over time and examining their relationship with their fund-raising and investment activities. Zacharakis and Shepherd (2001) found that VCs tend to be overconfident and this overconfidence tends to decrease their decision-making accuracy. By focusing on the construct of $\mathrm{VC}$ confidence and establishing trend information for it, we intend to add further context to the notion of 'over-confidence' and related aspects of VC intuitive decision-making (Khan, 1987).

We believe that discovered relationships between $\mathrm{VC}$ confidence and their fund raising and investment activities would provide an important contribution to our understanding of $\mathrm{VC}$ behaviour and the operation of their business model. For example, key studies that examine $\mathrm{VC}$ decision making with regard to investment criteria (Hall and Hofer, 1993), fund-raising (e.g., Gompers and Lerner, 1998) and syndication (Lockett and Wright, 2001) could be replicated with the inclusion of the VC confidence construct to determine if it provided for additional explanatory value. Additionally, if $\mathrm{VC}$ confidence was found to have a coincident or prescient relationship with fund raising and investment activities, then it could be used as a possible signal to entrepreneurs who rely on venture investment.

\section{Venture capitalists' confidence}

Measures of confidence among discrete groups, such as the University of Michigan Consumer Sentiment Survey and the Conference Board CEO Confidence Survey, are relied upon by financial market actors as they are thought to provide a leading indicator of economic vibrancy. Reasoning that if consumer confidence can provide an indicator of retail demand, we theorised that venture capitalists' confidence may provide a leading indicator of high-growth entrepreneurial activity. We sought to explore this proposition, and began tracking Silicon Valley venture capitalists' confidence in the future high-growth entrepreneurial environment in 2004. Each quarter since Q1 2004, we conducted a survey of a cross section of Silicon Valley VCs (typically 25-30 respondents) to determine $\mathrm{VC}$ confidence in the future high-growth entrepreneurial environment. These findings (the confidence index rating: 1 low -5 high, and VC commentary and author analysis) were provided in quarterly issued reports. (We discuss the process in more detail in the methods section and present the exact survey and the names and companies of most of the $\mathrm{VC}$ respondents in the appendices.) 
Since beginning issuing the quarterly reports on Silicon Valley Venture Capitalists' Confidence, a number of financial publications have cited it as a source to track VC confidence (e.g., The Wall Street Journal, CNBC Business Television, US News and World Report, BusinessWeek, Investor's Business Daily, National Public Radio, etc.), as well as being carried by ticker symbol on Bloomberg Professional Service for approximately 250,000 subscribers from the world's central banks, investment and commercial banks, government, corporate, and legal offices in more than 150 countries.

We sought to examine the relationship of this perceptual measure of change in $\mathrm{VC}$ confidence with actual capital commitments to VC funds and VC investments into their portfolio firms, along with the precedence of these relationships. For example, does an increase or decrease in $\mathrm{VC}$ confidence link to their ability to raise capital commitments for their funds or to their own investment plans in the near to medium term future? We had reason to believe so as indicated by commentary by a number of the VC respondents in our quarterly surveys. For example, in the 2008 Q1 Silicon Valley Venture Capitalists' Confidence Index Report (p.2),

Debra Beresini of Invencor attributed her sentiment partially to the fact that "New funds may have a challenge raising money until aggressive steps are taken to repair the damage which has been done in the financial markets."

In the same report, when asked to substantiate his confidence rating,

Mukul Singhal of Canaan Partners reasoned that "Institutional funding (Series A and later) will slow down a little but funds will keep investing because most of the funds raised money in 2006-2007."

Finally, in the 2007 2Q Report, an anonymous VC respondent confirmed that his confidence rested on the fact that "Fundraising and activity has been at very sustainable levels since the bubble days and is poised for high growth". With the validity of our preliminary enquiry buoyed by $\mathrm{VC}$ commentary in our surveys, we sought to better frame our investigation by uncovering additional prior research related to venture capitalists' confidence and to their fund-raising and investment activities.

\section{Literature review and hypotheses development}

Previous research has examined the factors that affect VC fundraising and investment. For example, Gompers and Lerner (1998), in their examination of VC organisations between 1972 and 1994 find that regulatory changes, capital gain tax rates, economic growth, R\&D expenditures and firm performance and reputation affect fundraising. Again, we refer to fundraising as capital commitments to venture capital funds. Gompers and Lerner (1998, p.160) defined commitments as "pledges that venture capitalists receive for investment over the lifetime of the fund. They are not the amounts invested in a given year". For example, once a Limited Partner (LP) has 'committed' \$10 million to a venture fund, the $\mathrm{VC}$ will periodically issue a 'capital call' for some portion of that commitment when a decision is made to invest in a new or current firm in the specific portfolio fund that the LP has committed capital to. This process of investing the committed funds may take several years. 
As noted earlier there is a rich literature in the evaluation of investment criteria and decision-making by venture capitalists. (Please see Zopounidis (1994) for an examination of this work.) More recently, Zacharakis and Shepherd (2001) tied VC overconfidence directly to their decision-making. And, performing a sociological investigation of syndication within the venture capital industry, Sorenson and Stuart find that

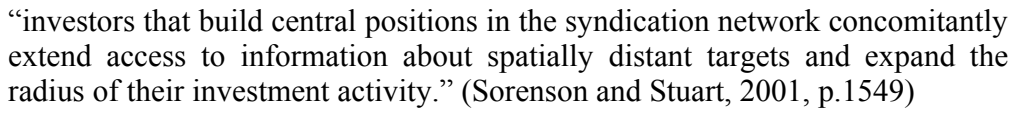

We offer that the increased knowledge that comes with this network centrality may also enhance overall confidence, thus bolstering the increased investment activity argument.

Other work related to investor psychology argued that the assessment of intangibles (Diaz De Leo and Guild, 2003) and venture team similarity to the venture investor (Franke et al., 2006), are an essential part of the investment decision process. Again, we contend that $\mathrm{VC}$ confidence is a function of this assessment and, therefore, worth monitoring. Further, Franke et al. (2008) find that VCs' experience plays a role in their evaluation of investment proposals. Specifically, they find that less experienced VCs value entrepreneurs with greater experience while more experienced VCs put greater weight on team cohesion. Here, again, we propose that VC confidence may be a function of experience and play a moderating role in this relationship.

Relating VC investment activity to the public market data, Jeng and Wells (2000) find that an increase in IPO valuations causes venture capital firms to increase fundraising while Gompers et al. (2005) find that the VCs with the most industry experience increase their investments as they interpret better public market signals. Other factors, also, affect the investment activity of venture capitalists. For example, Bernile et al. (2007) find that the optimal VC portfolio size (in terms of the number of firms in a VC fund) is positively related to the quality of entrepreneurs and the value of a successful project. While we agree that public market activity, network centrality and the availability of quality entrepreneurs will have a significant impact on the VC business model, we contend that venture capitalists' confidence provides a fuller explanatory variable in the VC business model. Specifically, we believe that VC confidence would have some relationship to how VCs pursue the various aspects of their business model; the two aspects of the VC business model we explore in this paper are fundraising and investment activity as they relate to our measure of $\mathrm{VC}$ confidence.

\subsection{VC confidence and capital commitments (fund raising)}

We sought to better understand the relationship between the broader construct of $\mathrm{VC}$ confidence and capital commitments. We reasoned that VC confidence could conceivably precede, be coincident with, or lag fundraising activity. Increasing VC confidence might precede increases in $\mathrm{VC}$ fundraising if $\mathrm{VC}$ confidence was primarily linked to the expectation of entrepreneurial talent, good deal flow and a welcoming public capital market. For example, if VCs felt confident that they could identify, develop and take public new portfolio firms, this increasing confidence would lead them to then raise new portfolio funds. In this case, increasing confidence precedes increased fund-raising. 
It also seems reasonable that higher $\mathrm{VC}$ confidence might lag behind increased fundraising activity in that $\mathrm{VC}$ confidence would presumably be higher as they had more committed investor financing for their funds in arrears. With increasing committed capital, carry fees of about $2 \% /$ year on the portfolio would also increase revenue to the VC firm and provide for a stronger base of operations. And a flush fund would give VCs greater flexibility in identifying and financing new high potential firms. Thus, higher operating income and greater flexibility in investment opportunities would presumably lead to higher confidence. In this case, increased fund-raising precedes increased $\mathrm{VC}$ confidence.

Finally, it seemed that $\mathrm{VC}$ confidence might be coincident with the current raising of funds because as VCs were in the process of fund raising they could determine immediately from the interested limited partners whether or not they were likely to complete their fund. This real time market knowledge of the receptivity of contributors to $\mathrm{VC}$ funds (e.g., pension fund and endowment managers) would seemingly have a real time impact on $\mathrm{VC}$ confidence as it is an essential component of their business model. In this case increased VC confidence is coincident with increased fund-raising.

We considered each of these potential relationships in the context of our ongoing discussions with practicing VCs and the extant literature and developed the following hypothesis.

H1: $\Delta$ Mean of Silicon VC confidence index (+/-) is contemporaneous with $\Delta V C$ capital commitments (fundraising activity) (+/-).

As stated in our first hypothesis we expect that changes in VC confidence will be concurrent with changes in $\mathrm{VC}$ fundraising activity and in the same direction. That is, an increase in fund raising (capital commitments) by quarter would run nearly simultaneously with an increase in $\mathrm{VC}$ confidence in the high-growth entrepreneurial environment.

\subsection{VC confidence and capital investment (financing portfolio firms)}

The second area of the VC business model we wished to explore in relationship to overall $\mathrm{VC}$ confidence was their investment activity in their portfolio firms. Similar to our logic on fundraising, we reasoned that VC confidence could conceivably precede, be coincident with, or lag behind investment activity.

Increasing $\mathrm{VC}$ confidence could conceivably precede increases in $\mathrm{VC}$ investment if VC confidence was primarily linked to a perceived ample supply of talented entrepreneurs, good deal flow, and a welcoming public market. In this case, VCs may feel more confident that they could identify, develop, and take public new portfolio firms; therefore, it would make sense to increase investment in their portfolio firms. In this case, increasing VC confidence would precede increased VC investment activity.

VC confidence could also lag investment activity as VCs would take some time to evaluate the success of their investment decisions over time - and that relative success would influence their overall confidence. In this case, increasing VC confidence would follow increasing investment activity. 
Finally, VC confidence could be concurrent with changing levels of investment activity as higher confidence would imply a concurrent higher level of investment in the same quarter and vice-versa. Given the real time nature of venture investing, we expected this relationship to be the case. Given our arguments above, and in the context of the extant literature and our ongoing discussions with VCs, we offer the following hypothesis.

H2: $\triangle$ MEAN of Silicon VC confidence index (+/-) is contemporaneous with $\triangle V C$ investment in portfolio firms (+/-).

As stated in our second hypothesis we expect that changes in VC confidence will be concurrent with changes in VC investment activity and in the same direction. That is, an increase in capital investment by quarter would run nearly simultaneously with an increase in $\mathrm{VC}$ confidence in the high-growth entrepreneurial environment.

\section{Sample description and methodology}

We conducted our analysis with data from two distinct sources - a primary sample of our longitudinal survey data, and archival financial market data over the same time frame. We hoped to provide a clearer and deeper understanding of venture capitalists' confidence with respect to objective measures of flows of committed capital to venture funds and investment flows to portfolio firms.

\subsection{Silicon Valley venture capitalist confidence index (independent variable)}

We collected our primary data from our quarterly surveys over three and one-half years, from Q1 2004 - Q2 2007 (14 quarterly observations). Each of the 14 surveys was conducted in the two weeks following the end of each calendar quarter. Each quarter's survey (email or paper) was sent to approximately 200 venture capitalists in the San Francisco Bay Area and averaged 25-30 respondents each quarter. Most of the responding venture capitalists agreed to allow their names and firms to be used as study participants, and they are listed in Appendix A. The survey provided data on each VC's self reported perceptual rating of confidence in the future high-growth entrepreneurial environment in the San Francisco Bay Area, usually with commentary supporting that rating. The survey may be found in Appendix B. VC perceptual measures of confidence were tabulated as the mean of the responses (which can take on values from 1 through 5 representing most pessimistic to most optimistic) and are calculated for each quarter. The survey results and full reports were issued in a coordinated release timed with their posting on Bloomberg Professional Service in the last week of the month following the calendar quarter. The reports were also provided to all survey participants and many other VCs for review and comment. To date, all of the comments by study participants and other venture capitalists who have read the report have been positive in nature.

Please see Figure 1 for a trend line of Silicon Valley venture capitalists' confidence from Q1, 2004 to Q2, 2007. These quarterly perceptual measures of venture capitalists' confidence also provided the absolute measure of confidence in the quarterly Silicon Valley Venture Capitalists Confidence Index reports. This measure has been referenced as an indicator of VC confidence by various financial publications (e.g., The Wall Street Journal, CNBC, etc.). 
Figure 1 Trend line of venture capitalists' confidence $Q 1$ 2004-Q2 2007 (see online version for colours)

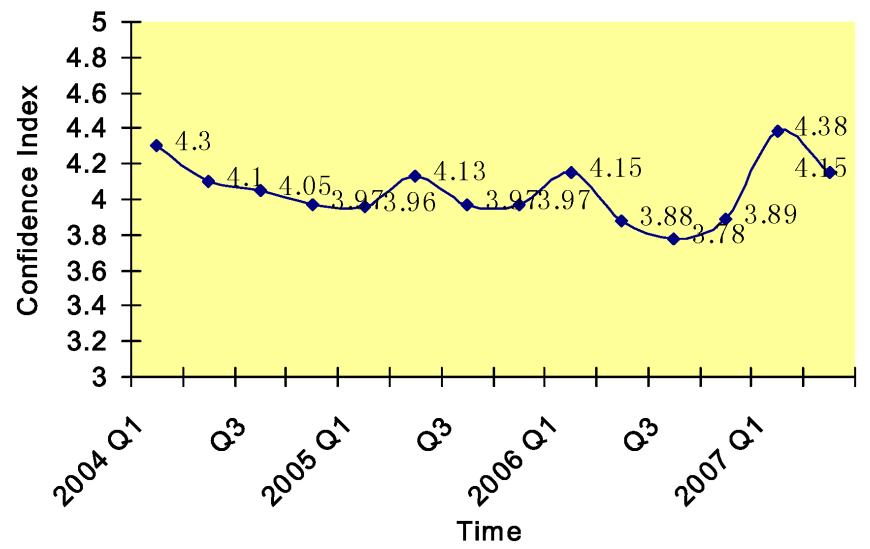

In the graph we see that there has been variance, albeit a somewhat modest variance in venture capitalists' confidence quarter to quarter over the last 3.5 years. Please see in Appendix A the total of all responding VCs who provided a perceptual measure in at least one quarter of our sample data. Unique to most survey studies, we make available the identities of the large majority of our survey participants as well as some of their direct quotes. We believe that providing our survey respondents' identities (with their permission) and including some of their direct 'on the record' commentary related to their assessment of their own confidence provides additional context and insight to our findings and add to the reliability and the relevancy of our study results.

\subsection{Dow Jones VentureOne data on US VC capital commitments and capital investments (dependent variables)}

To determine the relevance of our primary perceptual data we sought objective archival financial data that measured the capital commitments to VC funds and VC investments into their portfolio firms. We used archival financial market information provided by Dow Jones VentureOne. (Dow Jones VentureOne is recognised as the most comprehensive database on venture-backed companies and investors.) From it we gathered quarterly data on total dollar value of US capital commitments and capital investments of VC firms. Dollar values for total transactions overlapped the period of our own survey perceptual measures. Please see descriptive statistics for the study's period in Table 1. (Another application of the Dow Jones VentureOne data may be found in Cochrane (2005) where it was used in the assessment of the risk and return of venture capital. Kaplan et al. (2002) assesses the completeness of the Dow Jones VentureOne database.)

Using the quarterly survey results and capital commitment/investment data, we proceeded with a series of statistical tests to explore our theorised relationships. Additionally, our qualitative data (commentary from the responding venture capitalists) served to provide for an alternative view of the relationships (Yin, 1994). 
Venture capitalists' confidence, capital commitments

Table 1 Descriptive statistics on capital commitments and investments (dollars in millions)

\begin{tabular}{lccc}
\hline Year & Quarter & Capital commitments & Capital investments \\
\hline 2004 & 1 & $\$ 6,091.80$ & $\$ 5,597.11$ \\
2004 & 2 & $\$ 2,164.80$ & $\$ 6,067.50$ \\
2004 & 3 & $\$ 4,834.50$ & $\$ 5,309.55$ \\
2004 & 4 & $\$ 4,799.30$ & $\$ 5,436.33$ \\
2005 & 1 & $\$ 3,188.43$ & $\$ 5,200.26$ \\
2005 & 2 & $\$ 8,145.20$ & $\$ 6,775.44$ \\
2005 & 3 & $\$ 5,698.30$ & $\$ 6,109.69$ \\
2005 & 4 & $\$ 8,320.35$ & $\$ 6,032.61$ \\
2006 & 1 & $\$ 4,198.30$ & $\$ 6,465.15$ \\
2006 & 2 & $\$ 8,495.33$ & $\$ 6,886.82$ \\
2006 & 3 & $\$ 7,455.60$ & $\$ 7,225.11$ \\
2006 & 4 & $\$ 4,581.06$ & $\$ 6,280.38$ \\
2007 & 1 & $\$ 3,133.28$ & $\$ 7,047.20$ \\
2007 & 2 & $\$ 3,227.00$ & $\$ 7,437.31$ \\
\hline
\end{tabular}

\section{Regression results}

In our analysis of the relationships proposed in hypotheses 1 and 2 we examine the explanatory value of $\mathrm{VC}$ confidence on both capital commitment and capital investment dollar amounts by running a series of simple regressions. The simple regressions test for a relationship between the mean VC perceptual measure of confidence and inflows and outflows for the following cases:

- mean VC confidence measure vs. inflows and outflows for a lag of three months or time -1 (i.e., $\mathrm{VC}$ sentiment follows inflow/outflow activity)

- a contemporaneous relationship (time 0 ) between VC confidence and inflow/outflow activity

- mean VC confidence measure prior to inflow/outflow activity for the following quarter (time +1$)$.

We run our regression on the log of the dollar amounts of inflows and outflow dollars in order to obtain meaningful results, given the large dollar amounts of the dependent variables. In addition, any results obtained can then be interpreted as a change in the $\mathrm{VC}$ index contributing to a change in the dollar amount of inflow/outflow activity for the time period under consideration. These relationships under consideration are represented by the following formula.

Log (commitment $\$$ or investment $\$)_{-1,0,+1}=\alpha_{0}+\alpha_{1}$ CIMean 
where

commitment \$: money raised by VC partners from their limited partners to fund a specific venture fund and

outflow\$: money invested by VC to finance their portfolio firms' operations

CIMean: $\quad$ average response of quarterly confidence index.

Tables 2 and 3 present the results for the simplified model that estimates the $\log$ of committed and invested dollars for the quarter preceding, the same quarter, and the following quarter relative to the VC Confidence mean measure. The major finding in the first model is that the VC Confidence Index coefficient is significant and lags behind movement in committed dollars by 1 quarter. In addition, it is a negative relationship that is established by the regression results. This finding contradicts hypothesis 1 . In other words, a decrease in VC confidence at time 1 follows an increase in committed dollars at time 0 . There is no significant relationship between $\mathrm{VC}$ confidence change and committed dollar activity in any other time period tested (i.e., confidence is neither concurrent with nor does it precede dollar inflow activity. Numerically, the simple regression shows that a 0.1 decrease in the confidence index implies a $12.4 \%$ increase in inflows the preceding quarter.

Table 2 Simple regression results for time series of VC Confidence and capital commitments \$ activity

\begin{tabular}{lccc}
\hline Variables & Time $-1 \log ($ inflow $)$ dollars & Time 0 $\log ($ inflow $)$ dollars & Time $+1 \log ($ inflow $)$ dollars \\
\hline Constant & $4.9501^{*}$ & 2.0811 & -4.2858 \\
CI Mean & $-1.2370^{*}$ & -0.5286 & 1.07463 \\
$R^{2}$ & 0.0991 & 0.0253 & 0.0981 \\
\hline
\end{tabular}

Table 2 tests the significance of the variables in our model as outlined in equation (1). Significance levels for the results are reported as * which indicate $10 \%$ significance levels.

Table 3 Simple regression results for time series of VC Confidence and investment \$ activity

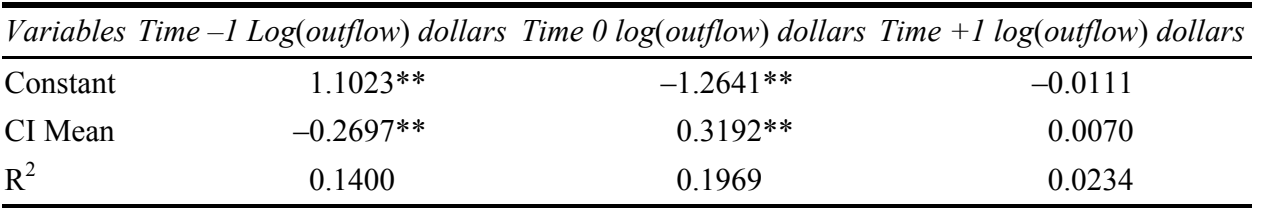

Table 3 tests the significance of the variables in our model as outlined in equation (1).

Significance level for the results are reported as $* *$ which indicate $5 \%$ significance levels.

Again, this runs counter to our initial hypothesis but leads to an interesting and non-obvious finding that is logical upon further reflection of the $\mathrm{VC}$ business model and the basic supply/demand relationship. That is, as more money flows into VC funds in mass - that extra supply of money will be chasing a limited number of good investment opportunities. The supply-demand relationship predicts that this increased supply of financing dollars in the venture industry will drive up the price of investing in new companies (in terms of receiving less equity in a new venture for a given amount of investment dollars) for each VC firm in the venture industry. This notion is consistent 
with the commentary from a number of VCs who responded to our surveys who cite this issue as one that tempers their optimism in the future high growth entrepreneurial environment. For example, in the 2Q 2007 survey,

Ross Jaffe of Versant Ventures noted "an excess of capital in the healthcare VC sector that is fueling too many companies getting funded and (driving) valuations up" for his declining confidence.

And in 3Q 2005 survey,

Randolph Tom of Dynasty Capital Services said that "The capital that is now available is at a very high, but dangerous level as once again quality deals are being met with more and more competitive term sheets."

It follows that as valuations of new firms become higher - it becomes more difficult for VCs to generate a favourable return on their invested dollars. This is, of course, because as $\mathrm{VC}$ firms pay more for a given equity position in a new venture, they must then be able to sell that ownership eventually, and must do so at a higher price in order to earn an adequate return on their invested capital. Thus, it seems reasonable that an increase in total financing committed to the venture industry leads to a decrease in average venture capitalist confidence as it negatively impacts their business model.

We obtain an interesting result for the relationship between the confidence index mean and invested capital or outflow dollar activity to portfolio financing. A positive significant coefficient on the mean results in time 0 indicates a contemporaneous positive relationship between $\mathrm{VC}$ confidence and the investment of $\mathrm{VC}$ funds to portfolio firms. Thus, our hypothesis 2 is supported. Numerically, the simple regression shows that a 0.1 increase in the confidence index implies a $3.2 \%$ increase in invested capital. This relationship is as projected and also makes sense from an investor psychology point of view. That is - VCs are confident at the time they make their investment in a new portfolio firm - believing that their due diligence in selecting a firm will lead to positive returns on their invested money. Essentially, they feel good about, or are confident in, their investment at the time that they make it. This finding is consistent with work done by Diaz De Leo and Guild (2003) who found that intangibles were very important during the investment decision process for early stage technology ventures.

However, we also find that confidence falls after an increase in investment capital from the previous quarter. Here we show that a .1 decrease in confidence in time 1 implies a $2.7 \%$ increase in investment activity in time 0 . In considering this counter finding we believe that this may be 'buyer's remorse' effect. That is to say that VCs show increasing confidence at the time of the increased investment activity, but begin to lose some confidence shortly after the initial 'honeymoon' effect with the portfolio firm. Perhaps in hindsight - some VCs become concerned that they overpaid for a stake in a new portfolio firm, or there is some type of buyer's remorse if the relationship between the investors and entrepreneurs comes under stress.

\section{Discussion and implications}

Our hypothesis 1, where we expected that VC confidence would have a positive and contemporaneous relationship with the commitment of LP funds to VC portfolios (VC fund inflows), was not supported. Rather, we found a relationship where an increase in LP committed funds to the VC industry has a leading temporal and negative 
relationship with $\mathrm{VC}$ confidence. That is, an increase of committed capital (as measured by total inflows to $\mathrm{VC}$ funds) preceded by one quarter a downtick in $\mathrm{VC}$ confidence.

This relationship at first appears to be counter intuitive, as VCs would seemingly be cheered by more committed capital to their funds as it provides them greater ability to invest in firms and generates a carry income (generally about $2 \%$ of committed funds) to run operations. However, upon further consideration and a review of commentary by $\mathrm{VCs}$ in the quarterly reports over the last four years, we expect that the total increase in committed funds to the VC industry essentially creates more competition (in terms of total committed dollars) or demand for a limited supply of attractive entrepreneurial deals. Therefore, as VCs note the increase in total committed funds to the industry from the previous quarter - they begin to expect that the excess of funds will drive up the cost for purchase of high potential entrepreneurial firms. This is borne out in VC comments (noted previously) for a lower confidence rating. Therefore, in retrospect, we have a non-obvious, but important, result from our investigation.

To summarise - an increase in total VC industry funds drives up the price of investing in new entrepreneurial firms and this higher cost - based on the supply/demand relationship - and tends to decrease confidence once individual VCs learn of the industry trends. This is consistent with the supply and demand function for any good; that is, a higher demand for a good (in this case demonstrated by more VC funds in the industry) tends to drive up the price for a good - (an entrepreneurial firm in terms of a given amount ownership equity for financing). This increase in price of potential new ventures in the $\mathrm{VC}$ market (not wholly dissimilar to price inflation in the consumer market) has the resultant effect of diminishing sentiment or confidence of the buyer (the venture capitalist in this case).

In hypothesis 2 we expected that as VC confidence increased so too would the funds they invested in portfolio firms. We did find this to be the case. Essentially, as VC confidence increased from $Q 1$ to $Q 2$ by 0.1 , we saw an increase in invested funds (VC financing of their portfolio firms) by $3.2 \%$ in the same time frame ( $Q 1$ to $Q 2)$. This expected result makes sense at face value. As venture capitalists' confidence increases in the future high growth entrepreneurial environment, so too do the funds they are apt to invest in their portfolio firms. Again, on reviewing the commentary of VCs explaining their high confidence, we find that they often comment on 'great entrepreneurial teams' or 'good deal flow' for their high confidence.

In exploring the same relationship, though, we found that $\mathrm{VC}$ confidence decreases one quarter after an increase in invested dollars. This runs counter to our expectations. In this case, we expect that there may exist an investor psychology component to this result. This is consistent with previous literature which has found that VCs tend to be intuitive decision makers (Khan, 1987). For example, this may be a buyer's remorse effect as the $\mathrm{VC}$ learns a bit more about the new portfolio firms and may regret the decision to invest in those companies or the price they paid for them.

\subsection{Implications for entrepreneurial firms}

Our findings suggest that VC confidence is coincident with investment in portfolio firms. Therefore, managers of high-growth enterprises in need of venture financing would be prudent to monitor $\mathrm{VC}$ confidence as it may be an indicator of investment flow. The relationship indicates that an increase in $\mathrm{VC}$ confidence is correlated with an increase in invested funds. Therefore, as might be expected, a more confident VC is 
more likely to invest in an entrepreneur's firm. As acquiring financing is a top role and priority of CEOs of new ventures, they may be able to make themselves more attuned of the likelihood and ease of obtaining financing by monitoring $\mathrm{VC}$ confidence on a quarterly basis.

Also relevant to entrepreneurs is our finding that as total committed funds to the venture industry increase, individual VC confidence tends to decrease. Again, a prudent entrepreneur may wish to monitor capital commitments in the venture industry as they appear to precede changes in VC confidence. In this case, an increase in committed funds to the venture industry tends to precede lower confidence at individual venture firms - perhaps due to concern over likely higher valuations.

\subsection{Implications for public policy}

As we view the VC process from an operational perspective - we see that their business model involves a certain pacing of operational tasks. That is, there are supply sources (entrepreneurs, technology and capital commitments from limited partners,), a transformation process (advising and coaching of portfolio firms along with financing of these firms), and a target market for their new company products (public capital markets - beginning with investment bankers, and other buyers of their equity position). An understanding of $\mathrm{VC}$ confidence may help to further illuminate each aspect of this business model. For example, VC confidence may be a moderating factor in the timing of the creation, development, and sale of their ultimate products (high-growth firms).

Therefore, regional and local governments may derive insights for their planning by tracking $\mathrm{VC}$ confidence, as it is suggestive of the development of new businesses that will create high calibre jobs and enhance local productivity. Further, since LP funds flow from a global base of capital to a regional hub of distribution (e.g., Silicon Valley) - regional growth may be forecast somewhat by closely following VC confidence and the resulting flow of funds into and out of their regional portfolio firms.

\subsection{Implications for theory and the existing literature}

We contribute to the literature in venture capital by introducing the construct of venture capitalist confidence and its relation to vital aspects of the VC business model. We believe that this new construct is important to consider across some strands of research in venture capital as it may be a moderating variable in certain presumed relationships. In this paper we view VC confidence in its linkages to committed and invested capital. While prior studies have examined the fund raising activities (capital commitments) of venture firms (e.g., Gompers and Lerner, 1998, etc.) and VC investments (e.g., Manigart et al., 2006; Hochberg et al., 2007), we have attempted to link these activities to the confidence held by venture capitalists, and, thereby, provide an additional view to these essential aspects of the VC business model.

Again, our findings suggest that venture capitalists' confidence has a meaningful relationship with $\mathrm{VC}$ fundraising and investing and, therefore, may influence the financing of entrepreneurial ventures. This result is complementary to existing literature that examines the decision process of venture capitalists. For example, Zacharakis and Shepherd (2001) found that VCs tend to be overconfident in making their investment decisions and that this overconfidence has a negative impact on their decision quality. Supporting this notion, we find that VCs' average measure of confidence appears to be 
well above average even during declining investment environments. And, as VCs have been shown to be intuitive decision makers (Khan, 1987), we propose that tracking VC confidence may provide a potential indicator of decision quality.

We intend for our contribution to spur future research in venture capital decision making to consider the potential moderating effect of $\mathrm{VC}$ confidence. There has been limited study of the impact of confidence on decision-making in general (Mahajan, 1992; Zacharakis and Shepherd, 2001). We propose that some studies which examine VC decision making in investment criteria and fund-raising could be replicated with the inclusion of the $\mathrm{VC}$ confidence construct to determine if it provided for additional explanatory value.

In our examination, we also highlight the impact of the supply/demand relationship of committed funds and potential investable ventures. Here, we see that as the supply of committed capital increases, $\mathrm{VC}$ confidence tends to decrease, possibly due to the higher expected price to be paid for equity positions. This is a non-obvious finding of our study, but upon reflection stands upon the well-accepted notion of supply and demand. In this case, as the commitments to industry venture funds increase en-masse (demand for venture-backed firms increases) with a constant supply of worthy new businesses to invest in, the price in terms of capital for equity in potential venture-backed increases and, thus, lowers the confidence of the VCs providing the financing. We believe this non-obvious result may provide fertile ground for further investigation by other researchers. For example, work could be done to examine the trends in capital commitments as they relate to fund performance, liquidity events, etc. Again, VC confidence may act as a moderating factor. Here, common assumptions that an increase in total capital dedicated to venture funds may not directly link to desired measures of industry and firm performance.

We also expect that there may be cognitive aspects at work with regard to $\mathrm{VC}$ confidence and their investment decisions (e.g., buyer's remorse). This may provide opportunities for researchers engaged in the investor psychology (e.g., Hirshleifer, 2001; Diaz De Leo and Guild, 2003; Franke et al., 2006) and VC experience (Franke et al., 2008) and VC overconfidence (Zacharakis and Shepherd, 2001) literature to expand their investigation in follow-up investigations. Finally, we propose that the 'on the record' commentary by our responding venture capitalists and listing of the names of nearly all our survey participants provide additional depth and validity to our findings upon which future studies can build.

\section{Limitations and future research}

As this is an early attempt to link the perceptual measures of VC confidence to capital commitments to, and investments from, venture capital firms, we readily admit that our findings should be interpreted with caution. Clearly, further study of these and associated relationships is needed. We limited our ongoing survey participants to Silicon Valley Venture Capitalists as we aimed to minimise some alternative variables that could be imbedded in geographical differences. However, examining the links between confidence of VCs in other USA regions and other nations with funding and financing decisions may be warranted to verify if the same relationships hold. 
We note that the ongoing sample of self-reported venture capitalists' confidence - averaging about 25-30 VCs each quarter, is relatively small. However, other researchers that contribute to the literature in venture capital will likely concur that soliciting an ongoing survey of VCs whose time is quite measured is a difficult task at best. Still, we do find a statistically significant relationship between this perceptual measure of VC confidence and capital commitments and capital investments. We suggest that future studies attempt larger sample sizes to unearth finer-grained relationships between VC confidence and other elements of the venture capital business model.

While we are confident in our findings, we also note that alternative explanations for our results may exist. To verify our results we encourage future studies to employ larger samples and alternative measures. Still, at present, we are pleased to raise the potential of new relationships for consideration in the rich stream of venture capital research.

We anticipate that fruitful future research may explore the link between all aspects of the VC business model and VC confidence. Determining any potential link between economic forecasts and consumer confidence with measures of $\mathrm{VC}$ confidence to better determine if $\mathrm{VC}$ confidence provides additional explanatory value to current leading indicators of economic activity may also be worthwhile. And, finally, a better theoretical understanding of the components of $\mathrm{VC}$ confidence and how it impacts the entrepreneurial process in high-growth enterprises that are essential to the national economy also bears investigation.

\section{References}

Bernile, G., Cummings, D. and Lyandres, E. (2007) 'The size of venture capital and private equity fund portfolios', Journal of Corporate Finance, Vol. 13, No. 4, pp.564-590.

Cochrane, J. (2005) 'The risk and return of venture capital', Journal of Financial Economics, Vol. 75, pp.3-52.

Cumming, D. (2006) 'The determinants of venture capital portfolio size: empirical evidence', Journal of Business, Vol. 79, pp.1083-1126.

Diaz De Leo, E. and Guild, P. (2003) 'Using repertory grid to identify intangibles in business plans', Venture Capital: An International Journal of Entrepreneurial Finance, Vol. 5, No. 2, pp.135-160.

Franke, N., Gruber, M., Harhoff, D. and Henkel, J. (2006) 'What you are is what you like - similarity biases in venture capitalists' evaluations of start-up teams', Journal of Business Venturing, Vol. 21, pp.802-826.

Franke, N., Gruber, M., Harhoff, D. and Henkel, J. (2008) 'Venture capitalists' evaluations of start-up teams: the trade-offs, knock-out criteria, and the impact of VC experience', Entrepreneurship Theory and Practice, Vol. 32, No. 3, pp.459-483.

Gompers, P. and Lerner, J. (1998) 'What drives venture capital fundraising?', Brookings Proceedings on Microeconomic Activity, National Bureau of Economic Research, Cambridge, MA, pp.149-192.

Gompers, P., Kovner, A., Lerner, J. and Scharfstein, D. (2005) Venture Capital Investment Cycles: the Impact of Public Markets, Working paper, National Bureau of Economic Research, Cambridge, MA.

Hall, J. and Hofer, C. (1993) 'Venture capitalists' decision criteria in new venture evaluation', Journal of Business Venturing, Vol. 8, No. 1, pp.25-42.

Hand, J. (2007) 'Determinants of the round-to-round returns of pre-IPO venture capital investment in US biotechnology companies', Journal of Business Venturing, Vol. 22, pp.1-28. 
Hirshleifer, D. (2001) 'Investor psychology and asset pricing', The Journal of Finance, Vol. 56, No. 4, pp.1533-1597.

Hochberg, Y., Ljungqvist, A. and Lu, Y. (2007) 'Whom you know matters: venture capital networks and investment performance', Journal of Finance, Vol. 62, No. 1, pp.251-301.

Jeng, L. and Wells, P. (2000) 'The determinants of venture capital funding: evidence across countries', Journal of Corporate Finance, Vol. 6, pp.241-289.

Kaplan, S., Sensoy, B. and Stromberg, P. (2002) How Well do Venture Capital Databases Reflect Actual Investment?, Unpublished Working Paper, University of Chicago, Chicago.

Khan, A. (1987) 'Assessing venture capital investments with noncompensatory behavioral decision models', Journal of Business Venturing, Vol. 2, pp.193-205.

Lerner, J. (1994a) 'The syndication of venture capital investments', Financial Management, Vol. 23, No. 3, pp.16-27.

Lockett, A. and Wright, M. (2001) 'The syndication of venture capital investments', Omega, Vol. 29, pp.375-390.

MacMillan, I., Siegel, R. and Subbanarasimha, P. (1985) 'Criteria used by venture capitalists to evaluate new venture proposals', Journal of Business Venturing, Vol. 1, pp.119-128.

Mahajan, J. (1992) 'The overconfidence effect in marketing management predictions', Journal of Marketing Research, Vol. 29, pp.329-342.

Manigart, S., Lockett, A., Meuleman, M., Wright, M., Landstrom, H., Bruining, H., Desbrieres, P. and Hommel, U. (2006) 'Venture capitalists' decision to syndicate', Entrepreneurship Theory and Practice, Vol. 30, No. 2, pp.131-153.

Shepherd, D. and Zacharakis, A. (2002) 'Venture capitalists' expertise: a call for research into decision aids and cognitive feedback', Journal of Business Venturing, Vol. 17, pp.1-20.

Sorenson, O. and Stuart, T. (2001) 'Syndication networks and the spatial distribution of venture capital investments', The American Journal of Sociology, Vol. 106, No. 6, pp.1546-1588.

Wilson, R. (1968) 'The theory of syndicates', Econometrica, Vol. 36, No. 1, pp.119-132.

Wright, M. and Lockett, A. (2003) 'The structure and management of alliances: syndication in the venture capital industry', Journal of Management Studies, Vol. 40, pp.2073-2102.

Yin, R. (1994) Case Study Research: Design and Methods, 2nd ed., Sage Publishing, Beverly Hills, CA.

Zacharakis, A.L. and Shepherd, D.A. (2001) 'The nature of information and overconfidence on venture capitalists' decision making', Journal of Business Venturing, Vol. 16, pp.311-332.

Zopounidis, C. (1994) 'Venture capital modeling: evaluation criteria for the appraisal of investments', The Financier ACMT, Vo. 1, May, pp.54-64.

\section{Notes}

${ }^{1}$ Confidence is a necessary element to the proper functioning of financial markets and it continues to be a closely watched metric of the national economy. CEOs and consumers are regularly surveyed as to their perception of confidence in business conditions as their sentiment may provide a leading indicator of macro-economic health. Venture capitalists play an essential and growing role in the development of high potential ventures that support the entrepreneurial nature of the US economy; however, VC sentiment has not before been systematically tracked; neither has it been linked to the functioning of the VC business model.

${ }^{2}$ A 2007 Global Insight Report indicates that companies which were once venture-backed but are now public account for 10.3 million jobs and $18 \%$ of US GDP.

${ }^{3}$ Merriam-Webster online dictionary. Accessed 8 September 2008. 
Appendix A: Venture capitalists who provided 'on the record' confidence ratings and commentary for one or more quarterly surveys

\begin{tabular}{|c|c|}
\hline Participant & Company \\
\hline Alex Osadzinski & Trinity Ventures \\
\hline Andy Brooks & Cresendo Ventures \\
\hline Andy Donner & Great Spirit Ventures \\
\hline Ann Winblad & HummerWinblad \\
\hline Annie Hazlehurst & Draper Fisher Jurvetson \\
\hline Arno Penzias & New Enterprise Associates \\
\hline Barbara Santry & Capstone Ventures \\
\hline Bart Schachter & Blueprint Ventures \\
\hline Ben Chen & Burrill and Company \\
\hline Ben Dubin & Asset Management \\
\hline Bill Baumel & RWI Ventures \\
\hline Bob Pavey & Morgenthaler \\
\hline Brendan Richardson & Vision Capital \\
\hline Bruce MacNaugton & Crosslink Capital \\
\hline Bryant Tong & Nth Power \\
\hline Casper de Clercq & U.S. Venture Partners \\
\hline Charles Beeler & El Dorado Ventures \\
\hline Chester Wang & Acorn Campus \\
\hline Chris Ehrlich & Interwest Partners \\
\hline Claas Heise & Innovature Capital Partners \\
\hline Colin Wiel & Keiretsu Forum San Francisco \\
\hline Curtis Lee & Advanced Technology Ventures \\
\hline D. Kirk Westbrook & invencor \\
\hline Dag Syrrist & Vision Capital \\
\hline Dan Skaff & Sienna Ventures \\
\hline Dave Messner & Amsterdam Pacific Securities \\
\hline David Epstein & Crosslink Capital \\
\hline David G. Arscott & Compass Technology Partners \\
\hline David Haselwood & Burrill and Company \\
\hline David Hornik & August Capital \\
\hline David Pidwell & Alloy Ventures \\
\hline David Spreng & Crescendo Ventures \\
\hline Debra Guerin Beresini & invencor \\
\hline Deepak Kamra & Canaan Partners \\
\hline Dick Kramlich & New Enterprise Associates \\
\hline Dino Vendetti & Bay Partners \\
\hline Dixon Doll & Doll Capital Management \\
\hline Elaine Bailey & Novus Ventures \\
\hline Eric Buatois & Sofinnova Ventures \\
\hline Eric Sigler & BA Venture Partners \\
\hline
\end{tabular}


Appendix A: Venture capitalists who provided 'on the record' confidence ratings and commentary for one or more quarterly surveys (continued)

\begin{tabular}{|c|c|}
\hline Participant & Company \\
\hline Evgeny Zaytsev & Asset Management Company \\
\hline Fred Dotzler & De Novo Ventures \\
\hline Gary Little & Morgenthaler Ventures \\
\hline Gilman Louie & Alsop-Louie Partners \\
\hline Giovanni Ferrara & Burrill and Company \\
\hline Graham Burnette & Red Planet Capital \\
\hline Gregory Gretsch & Sigma Partners \\
\hline Guy Kawasaki & Garage Technology Ventures \\
\hline Gustavo Alberelli & Trinity Ventures \\
\hline Henry Wong & Novus Ventures \\
\hline Ian Patrick Sobieski & Band of Angels \\
\hline Igor Sill & Geneva Venture Partners \\
\hline J. Sanford Miller & $3 \mathrm{I}$ \\
\hline Jacques Vallee & SBV Venture Partners \\
\hline James Lung & VenGlobal Capital \\
\hline Jan Barker & MedVenture Associates \\
\hline Jay Watkins & De Novo Ventures \\
\hline Jeb Miller & ComVentures \\
\hline Jim Marshall & Selby Venture Partners \\
\hline Jim Swallow & Monterey Investors Roundtable \\
\hline Jim Watson & CMEA Ventures \\
\hline Joe Mandato & De Novo Ventures \\
\hline John Borchers & Cresendo Ventures \\
\hline John Kohler & Redleaf Venture Management \\
\hline John Turner & Vision Capital \\
\hline Karl Handelsman & CMEA Ventures \\
\hline Ken Kelley & LVP Capital \\
\hline Kent Goldman & Venture Strategy Partners \\
\hline Kurt Keilhacker & TechFund Capital \\
\hline Kwan Yoon & Nokia Venture Partners \\
\hline Linus Lundberg & Vision Capital \\
\hline Marco DeMiroz & Selby Venture Partners \\
\hline Matthew Pedley & Minah Ventures \\
\hline Michael K. Lee & Dominion Venture Partners \\
\hline Mike Carusi & Advanced Technology Ventures \\
\hline Mike Rocke & Rocke Capital Ventures \\
\hline Mohanjit Jolly & Garage Technology Ventures \\
\hline Peter Dumanian & Red Rock Ventures \\
\hline Peter L. Wolken & Diamond Head Ventures \\
\hline Peter Wolken & Diamondhead Ventures \\
\hline Peter Ziebelman & Palo Alto Venture Partners \\
\hline
\end{tabular}




\section{Appendix A: Venture capitalists who provided 'on the record' confidence ratings and commentary for one or more quarterly surveys (continued)}

\begin{tabular}{|c|c|}
\hline Participant & Company \\
\hline Prashant Shah & Hummer Winblad Venture Partners \\
\hline Raj Atluru & Draper Fisher Jurvetson \\
\hline Randy Hawks & Claremont Creek Ventures \\
\hline Richard Yen & Blueprint Ventures \\
\hline Rob McIntosh & Arrow Path VC \\
\hline Robert C. Marshall & Selby Venture Partners \\
\hline Robert R. Ackerman Jr. & Allegis Capital \\
\hline Robert Troy & Geneva Venture Partners \\
\hline Ron Conway & Angel Investors \\
\hline Ross Jaffe & Versant Ventures \\
\hline Sanford Miller & 3i Group \\
\hline Sanjay Subhedar & Storm Ventures \\
\hline Scott Sandell & New Enterprise Associates \\
\hline Sergi Martorell & 3i Group \\
\hline Sharon Wienbar & BA Venture Partners \\
\hline Shomit Ghose & Onset Ventures \\
\hline Skip Fleshman & Asset Management \\
\hline Standish O,Grady & Granite Ventures \\
\hline Stephen J. Harrick & Institutional Venture Partners \\
\hline Stephen J. Sullivan & Skyline Ventures \\
\hline Steve Carnevale & Point Cypress Ventures \\
\hline Steve Dow & Sevin Rosen Funds \\
\hline Steve Harrick & Institutional Venture Partners \\
\hline Stewart Alsop & New Enterprise Associates \\
\hline Thomas D. Fountain & Mayfield Fund \\
\hline Tim Wilson & Partech International \\
\hline Tom Baruch & CMEA Ventures \\
\hline Tom Cole & Trinity Ventures \\
\hline Tom Fountain & Mayfield Fund \\
\hline Tom McKinley & Partech International \\
\hline Tom Rosch & InterWest Partners \\
\hline Tzu-Hwa Hsu & Walden International \\
\hline Venky Ganesan & Globespan Capital \\
\hline Wade Woodson & Sigma Partners \\
\hline Wende Hutton & Canaan Partners \\
\hline Zack Scott & Burrill and Company \\
\hline
\end{tabular}


The authors wish to thank the participating venture capitalists who generously provided their expert analysis and commentary. Since the time of the surveys conducted, some of the responding venture capitalists listed above have moved to other firms.

\section{Appendix B: Quarterly survey for Silicon Valley venture capitalists' confidence index}

\section{Dear}

Please consider contributing your insight to the Silicon Valley Venture Capitalist Confidence Index. The Index results are carried on the Bloomberg Financial Network (ticker: SVVCI) in 125 countries and have been featured in the Wall Street Journal, Business Week, San Jose Mercury News, CNBC, and more.

We ask you to respond to the questions below for your insight to be included in our upcoming report. (Previous reports may be read at the following link for your reference http://www.usfca.edu/sobam/nvc/pub/svvcindex.html). We will forward this quarter's complete report to its contributors on the official release date later this month. Please indicate your response in your reply to this note at your earliest convenience.

Thank you for supporting entrepreneurship research and education.

Mark V. Cannice, PhD

Associate Professor of Entrepreneurship

University of San Francisco School of Business

Please respond to the questions below for your input to be included in our upcoming report.

1. Please indicate your confidence in the future high-growth venture entrepreneurial environment (next 6-18 months) in the SF Bay Area.

$\begin{array}{lcccc}\text { Low } & \text { Medium } & & \text { High } \\ 1 & 2 & 3 & 4 & 5\end{array}$

Your answer:

1a. May we include your name/company as a participant for this index study (not associated with your number rating)?

2. (Optional comment) What is the primary cause of your above rating?

2a. May we use your name with this comment?

Thank you again.

Mark V. Cannice, PhD (cannice@usfca.edu)

Executive Director, USF Entrepreneurship Program

University of San Francisco 